\title{
AN ANALYSIS OF DEDUCTIVE AND INDUCTIVE APPROACHES IN TEACHING GRAMMAR AT SMPN 2 KOTA TANGERANG ${ }^{1}$ Abdul Rohim, ${ }^{2}$. Dania Farahdila ${ }^{3}$ Yudhi Indra Gunawan
}

\author{
1 abdulrohim2013@yahoo.com \\ 2daniafarahdila29@gmail.com \\ 3 yudhi.indra@umt.ac.id
}

\begin{abstract}
The objective of this research is to know and analyze the deductive and inductive approaches in teaching grammar used by english teachers at SMPN 2 Kota Tangerang. The researchers used descriptive qualitative method. The data of this research were collected through the observation of teaching and learning activities in the classroom of four english teachers at SMPN 2 Kota Tangerang. The result of the research showed that the four english teachers used either deductive approach or inductive approach, it can be seen from the way they were teaching, they chose and used either deductive approach or inductive seen by the steps that implemented by the teacher in teaching grammar, the role of teacher and students in the teaching and learning activities. The three of four English teachers at SMPN 2 Kota Tangerang used or applied deductive approach in the classroom and one of them still used and applied inductive one. As for the used of an approach, the researchers got a result of the dominance approach used by the English teachers at SMPN 2 Kota Tangerang was deductive.
\end{abstract}

\section{Key words: Deductive, Inductive, Teaching Grammar..}

\section{INTRODUCTION}

English is an international language and lingua franca, it is important for other countries especially developing countries such as Indonesia should consider English as important language. In contrast, English is rarely used by Indonesian in their daily conversation and daily activities, it is used by Indonesian only for business, tourism, science, technology, international seminar, and instruction or procedure of how to use something. The Indonesian who be able to speak English fluently usually people who lives in or around capital city (Jakarta) and the town that mostly visited by tourist from other countries such as Bali, it is because some people still consider English as difficult language and as unimportant language that they do not appreciate english as native language if they learn and speak English.

In the term of education in Indonesia, English has been taught in Indonesian school, start from elementary school or even there are some playgroups and kindergarten to senior high school, based on Permendiknas in 2006 about Kurikulum Tingkat Satuan Pendidikan (KTSP) or School- Based Curriculum which attachs English as one of the compulsory subject in middle schools and senior high school, and it is still being compulsory object although the curriculum changed into K-13 or Student-Based Curriculum. K-13 or Students Based Curriculum means that the curriculum required teacher to choose approach, method, technique, and strategy that students oriented or students more active and teacher talk time is less, the function of teacher is not as source but as facilitator in teaching - learning process. 
Globish (An English-Indonesian journal for English, Education and Culture

Vol. 10, No.2, July 2021,

P-ISSN: 2301-9913, E-ISSN: 2597-9132

DOI: http://dx.doi.org/10.31000/globish.v7i2

Because it is students oriented, this curriculum expected will make students more active in acquiring knowledge, skills, and strategies. Besides being taught at school, English also being taught in informal way approved by there are some English private course and English can be learned through media such as Youtube, Instagram, or online private course.

In the term of education, the purpose of education is realized through the process of education, therefore, education plays an important role in developing the potential that has been owned by human and education is vehicle for learner to get knowledge. The important part of education is educator or usually called teacher or lecturer, a teacher or an educator should prepare an appropriate approach, method, and technique that will be used in the classroom which might be different in each class. The reasons are because the appropriate approach, method, and technique will make easier for teacher in explaining the material and make students easier in understanding the material, so the teaching and learning activity is well organized and successful as the objectives of the lesson are reached. If you are English teacher or lecturer, you have to teach or educate four integrated skills to your students. Those skills are listening, speaking, reading, and writing, Harmer (2001) divided those four skills into receptive skills (reading and listening) and productive skill (writing and speaking), means that in real word when we study language we learn to speak by what we hear and we learn to write by what we read, those skill have to deliver by time limitation in teaching which only $2 \times 1$ hour lesson (45 minutes) or 90 minutes in a week. The good understanding and knowledge of grammar that include what, when, and how to use the knowledge is a basic language component that need to be mastered by teacher in teaching those skills to their students beside other language components such as vocabulary, spelling, and pronunciation. It is likely grammar is the main basic of language components, but it does not mean vocabulary, spelling, and pronunciation are not important to be mastered by teacher, those all language components are also fundamental and important to be mastered by teacher.

Grammar, a word that probably you heard most since elementary school till senior high school if English is considered as second language or foreign language in your country, undoubtedly considered as one of main part or main component of language. The statement is supported by Andrea Decapua"s statement that in order to make coherent and meaningful sentences, grammar guide speakers in how to string symbols, sounds, and words are string together, that is why grammar is blueprint of language (Decapua, 2008, p. 9). Therefore, as a language teacher or educator, grammar is included when teacher teach those four skills because students have to write and speak in correct grammar structure, they also have to know the grammar of what they listen and read correctly in order to understand what they listen and read as there is tendency of misunderstanding or misconception if there is mistake in grammar usage and understanding. In other word, grammar is important, so, the ability of grammar knowledge and understanding should be mastered and teach by teacher in order to make the students will understand and master it too.

There are two approaches that usually used by teacher in teaching grammar, the first is deductive approach which considered as traditional approach that primarily focusing on form 
Globish (An English-Indonesian journal for English, Education and Culture

Vol. 10, No.2, July 2021,

P-ISSN: 2301-9913, E-ISSN: 2597-9132

DOI: http://dx.doi.org/10.31000/globish.v7i2

so it is like teacher centered learning and the second is inductive approach which considered as modern approach that based on a specific language function in correlation with a specific context and meaning that like student centered learning. The statement is supported by Amstrong. D.G (1999) that "Inductive (part-to- whole) and deductive (whole -to-part) approaches are two of the varying methods of content organization" (Yürük, Şahl'n, \& Bozkurt, 2000). Whatever approach teacher uses, choose the appropriate approach which should consider students profile that includes students" level of knowledge and the approach should be done in interesting and fun way because mostly students consider grammar as difficult to be learned as the grammar not being taught how it should be that make students do not understand why grammar rules applied and worked the way it does, they are simply told what they should do and expected to repeat it enough times to know it by heart. Finally, based on explanation above, the researcher chooses to know the comparison between deductive and inductive approach in teaching grammar with the title: An Analysis of Deductive and Inductive Approaches in Teaching Grammar at SMPN 2 Kota Tangerang.

\section{THEORITICAL FRAMEWORK}

1. Teaching Grammar

A. Definition of Grammar

Learning and teaching language cannot be separated with grammar as it is the basic knowledge beside pronunciation and vocabulary that should be understood and mastered by teachers in order to teach the lesson to their students. Therefore, the definition of grammar itself should be understood by teacher before teaching grammar.

In this research, the researchers include the definition from grammar from some experts. Nunan (2003, p.154) stated at the sentence level, grammar is considered as a set of rules specifying the correct ordering of words.

Furthermore, Kroeger (2005, p. 5) stated the term grammar is often used to refer to the complete set of rules needed to produce all the regular patterns in a given language. Another, perhaps older, way in which the term grammar is sometimes used means roughly "all the structural properties of the language except sound structure (phonology)," i.e. the structure of words, phrases, sentences, texts, etc.

In addition, Berry (2012, p .4) stated "Grammar is the system of rules that enables users of a language to relate linguistic form to meaning".

Based on the theories above, the writers concluded the definition of grammar is a complete set of rules that needed in order to specify the correct ordering of the structure of words, clauses, phrases, and sentences in any given language, so users of language enable to relate linguistic form to meaning.

\section{B. Concept of Teaching Grammar}

Language teaching and grammar teaching were synonymous in most language classrooms thirty years ago with the primary aim of teaching was to ensure that learners mastered the grammar, pronunciation and vocabulary of the language (Nunan, 2003, p. 155). Nowadays teaching grammar takes a primary and important role in learning and teaching 
Globish (An English-Indonesian journal for English, Education and Culture

Vol. 10, No.2, July 2021,

P-ISSN: 2301-9913, E-ISSN: 2597-9132

DOI: http://dx.doi.org/10.31000/globish.v7i2

process because grammar is included in learning and teaching process such as in assignment, test, explanation, and textbook whatever skill (writing, reading, speaking, and listening) that being taught by teacher to their students in the classroom. In other word, Grammar teaching sometimes happens as a result of other work the students are doing for example, when they study language in a text they have been reading or listening to, or when a grammar problem presents itself unexpectedly in the middle of lesson and we feel we have to deal with it on the spot. "Grammar teaching may grow directly from the tasks students are performing or have just performed as part of a focus on form approach "(Harmer, 2007, p. 210).

Similar as teaching in general, teaching grammar is also challenging for teachers because besides requires teachers to understand the material that will be taught to their students it also require them to prepare things that Edward Anthony (1963) in Brown (2000, p.14) identified as three hierarchical levels of conceptualization and organization of language teaching, which termed as approach, method, and technique.

Furthermore, Anthony defined approach, method, and technique as follow: an approach is correlative assumptions or beliefs about the nature of language teaching and learning. An approach is axiomatic, it describes the nature of the subject matter to be taught. Method is an overall plan for orderly presentation of language material, no part which contradicts, and all of which is based upon, the selected approach. An approach is axiomatic, a method is procedural, within one approach, there can be many methods. A technique is any specific activities in a classroom such as excercises or task that must be consistent with a method, and therefore in harmony with an approach as well.

In addition, there are two factors in basic principles as teaching grammar which termed efficiency factors (economy, ease, efficacy) and approciacy factor (the age of the learners, their level, the size of the group, the constitution of the group, e,g. monolingual or multilingual, what their needs are, e.g. to pass a public examination, the learners' interests, the available materials and resources, the learners' previous learning experience and hence present expectations any cultural factors that might affect e.g. their perception of the role and status of the teacher, the educational context, e.g. private school or state school, at home or abroad (Thornbury, 2002, p. 25).

\section{Deductive and Inductive}

\section{A. Defination of Deductive and Inductive}

The appropriate approach that might be different in every class because considering many factors is needed to be applied in the classroom in order to achieve the objectives of the lesson. Brown (2000, p. 365) stated there are two approaches when teaching grammar arises which termed as deductive (rule - driven) and inductive (rule - discovery).

Furthermore, Brown explained a deductive approach means a rule of grammar is learned through explanation from the teacher or textbook then students practice through the example in which the rule is applied.

Another explanation of the deductive approach is by Thornbury (2002, p. 29) that stated deductive approach is teaching by giving a presentation of rule followed by examples in which the rule is applied. 
Globish (An English-Indonesian journal for English, Education and Culture

Vol. 10, No.2, July 2021,

P-ISSN: 2301-9913, E-ISSN: 2597-9132

DOI: http://dx.doi.org/10.31000/globish.v7i2

In line with Thornbury, Nunan (2003, p. 158) stated in the deductive classroom teachers try to help learners understand and clarify the point of grammar by giving a grammatical explanation or rule followed by a set of exercises.

Furthermore, Stern (1992) in Walterowicz (2013, p. 117) described and analyzed a deductive approach in terms of a systematic sequence of three stages as presented below:

1. Rule: The teacher explicitly formulates and clarifies the rule;

2. Example: An exemplary way to properly apply the particular rule in the actual use of language is introduced by the teacher;

3. Practice: Students are assigned a new task by the teacher and they have to complete the task based on the interpretation of the teacher have been presented previously.

From the explanation above, it can be concluded the definition of deductive approach is when rules of grammar are explained explicitly by the teacher from general to specific in order to get similar perception then followed by example and practice to make students more understand about the rule. In other word, the role of teacher in this approach is as facilitator that organize and control students to get knowledge of rule of grammar that should be easy to bes followed and practiced by students when they do an exercise, so a deductive approach can be considered as teacher-centered learning because the role of the teacher is more domininat than the students.

\section{B. Defination of Inductive approach}

The other approach besides the deductive approach that usually used by a teacher in teaching grammar is inductive approach, there are some definitions of the inductive approach by experts that will be discussed in the following paragraph.

Brown (2000, p. 365) stated an inductive approach means teacher gives practice of various language forms then let learners to discover or induce rules and generalization on their own.

Another definition is from Thornbury (2002, p. 49) that stated an inductive approach or rule - driven would seems to be the natural way or route in acquiring language, in an inductive approach the learners are not introduced the rule but they unconsciously experiencing study from exposure of the examples by their teacher to derive an understanding of regularities and patterns of the language.

Meanwhile, Nunan (2003, p. 158) stated reverse to deductive approach, in inductive approach learners are presented the samples of language and then let learners to workout the principle of rule by themselves through the process of guided discovery.

Furthermore, Stern (1992) in Walterowicz (2013, p.117) described and analyzed the inductive approach in terms of a systematic sequence of three stages as presented below:

1. Introduction 
Globish (An English-Indonesian journal for English, Education and Culture

Vol. 10, No.2, July 2021,

P-ISSN: 2301-9913, E-ISSN: 2597-9132

DOI: http://dx.doi.org/10.31000/globish.v7i2

The students are assigned a new task by the teacher and then the teacher presents an exemplary way to deal with the task.

2. Practice

The students complete the task based on their assumptions which connected with the example given by the teacher.

3. Rule

The students formulate the rules based on their assumptions through inductive inference, then the teacher clarifies the rule.

Meanwhile, Atta, Ayaz, and Nawaz (2015, p. 21) stated four steps in applying inductive approach as presented below :

1. Appearance/presentation of Examples

In this step, lot of examples of same type are shown by teacher and after that solutions of all those specific examples are obtained with the help of the students.

2. Observation/Reflection

After all those specific examples are solved, the students detect and observe those examples to reach the conclusion of rules of grammar.

3. Generalization (Simplification)

After students get conclusion based on their perception through observe the examples, the educator and students do a logical mutual discussion of rules, laws, and formula in order to get similar perception of the material.

4. Testing and verification (authentication)

Law, rule, or principle are tested and proved by students through other suitable specific examples.

Based on the explanation above, it can be concluded the definition of inductive approach is a natural way in acquiring language in which the learners are learning regularities and patterns unconsciously through the examples that given by the teacher and then they discover or induce the rules and generalization on their own through the process of guided discovery. In other words, the roles of teacher are as guidance and helper for students to get knowledge of rules of grammar, so this approach is more students centered approach because the role of the students is more dominant than the teacher.

\section{RESEARCH METHODOLOGY}

The method used in this research is descriptive qualitative method and taken place in the real situation or naturally happen without any treatment given by the researchers, it is very unjustified to manipulate or change background of the research. The research was conducted on a sample of 4 english teachers belonging to SMPN 2 Kota Tangerang. The technique of data collecting that has been done by the researchers was observation of teaching and learning activities in the classroom of english teachers. Observation is the activity of researcher directly to the classroom to get the data in order to know whether the activities have reached the objectives of the study and to get information about the real condition in teaching learning activities. 


\section{RESEARCH FINDING AND DISCUSSION}

\section{Research Finding}

In this research, the researchers have main objective to know and analyze the deductive and inductive approaches in teaching grammar used by english teachers at SMPN 2 Kota Tangerang. The researchers collected the data through observation of teaching and learning activities in the classroom of english teachers at SMPN 2 Kota Tangerang. The observations have been done by the researchers through four english teachers at SMPN 2 Kota Tangerang. The researchers also analyze the data, which is qualitative, into several findings:

Result of observation of teaching and learning Activities in the classroom, the researchers did an observation of teaching and learning activities in the classroom to four English four teachers at SMPN 2 Kota Tangerang to support the data and to know how the teachers implemented the approach in teaching grammar.

\section{a. The first teacher}

The first teacher begins the lesson with regular activities (greeting the students, praying, and checking the students' attendance). Then, the teacher gives presentation of examples by asking the students about their activity in the morning then asking them to write it on the whiteboard while asking the students to observe about the subject, verb, and object of the sentence in the simple present tense form. Next, teacher does generalization by explaining to the students that they actually learn about simple present tense then the teacher writes on the whiteboard the definition, formula of the positive, negative, affirmative pattern of simple present tense while recall students' memory about a subject, verb, and object from a sentence in the simple present tense form through question and answer then let the students write the material on their notebook. Next, the teacher writes on the whiteboard short dialogue which includes a sentence in the form of simple present tense and asks the students to read together. The last, teacher does the test and verification by asking the students to make other short dialogue based on the material that the students have learned.

\section{b. The second teacher}

The second teacher begins the lesson with regular activities (greeting the students, praing, and checking the students' attendance). Then, the teacher asks the students to open the textbook and reviews the previous lesson about asking and giving an opinion. Next, the teacher starts to introduce the rule by reading the sentence about expression to show appreciation in the textbook while explaining part of speech of the sentence. Next, the teacher writes on the whiteboard other examples besides that have already been mentioned in the textbook while explaining part of speech of the sentence. Next, the teacher gives first practice by asking students to make three sentences about expression to show appreciation and reading it in front of the classroom with their tablemate. The last, the teacher gives second practice by asking the students to make five short dialogue expressions to show appreciation. 


\section{c. The third teacher}

The third teacher begins the lesson with regular activities (greeting the students, praing, and checking the students' attendance). After that, the teacher asks the students to open their textbook about healthy life (the title of the second chapter). Next, the teacher introduces the rule by reading short sentence in the textbook and asking them to repeat it, then the teacher writes the the formula or pattern, its functions, and meaning of sentences which purposed to state purpose or intention to do something (in order to, so that, so, to, in order not to) followed by examples. After that, the teacher let the students to write the material on their notebook and gives the first practice by letting them to make their version of sentences which purposed to state purpose or intention to do something (in order to, so that, so, to, in order not to). Last, the teacher gives second practice by asking four students to write their sentences on the whiteboard.

\section{d. The fourth teacher.}

The fourth teacher begins the lesson with regular activities (greeting the students, praing, and checking the students' attendance). After that, the teacher reviews the previous lesson about simple present tense through question and answer. Next, the teacher writes the definition, formula of the positive, negative, affirmative pattern of simple past tense, and example on the whiteboard while recall students" memory about a subject, verb, and to be from a sentence in the simple past tense form then let the students write the material on their notebook. Last, the teacher writes on the whiteboard another positive sentence of simple past tense and asks two students to change the sentence into negative and affirmative pattern.

\section{Discussion}

Here the discussion based on the observation of teaching and learning activities in the classroom.

\section{The first teacher.}

The implementation of the teaching and learning activities of the first teacher shows that the teacher applies inductive approach in teaching grammar, approved by the rules of grammar are explained implicitly or indirectly from specific to general thing or from example as introduction followed by observation and generalization then testing and verifying in the context of students" activity in the morning to attract attention from the students as the focus is communicative purpose is in line with statement by Atta, Ayaz, and Nawaz (2015, p.21) that there are four steps in applying inductive approach, start from example followed by observation and generalization then testing and verivication.

Furthermore, the opportunity by the teacher for the students to be active is provided as there is communication activity in the practice between the students and encourage the students by giving them freedom to make other short dialogue, so the students do not depend on the teacher instruction or explanation and the role of the students is more 
Globish (An English-Indonesian journal for English, Education and Culture

Vol. 10, No.2, July 2021,

P-ISSN: 2301-9913, E-ISSN: 2597-9132

DOI: http://dx.doi.org/10.31000/globish.v7i2

dominant than the teacher that makes teaching and learning activities more likely as studentscentered learning.

\section{The second teacher}

The teaching and learning activities that implemented by the second teacher signed the teacher applied inductive approach in teaching grammar, approved by the steps of the second teacher that explained grammar explicitly from the rule then example followed by practice to get direct attention from the students to focus on the form of the rule of grammar or in other words directly from general to specific things is in line with statement by Stern (1992) in Walterowicz (2013, p.117) that stated there are three steps in applying deductive approach, start from the rule then example followed by practice.

In addition, the opportunity by the teacher for the students to be active is provided, but the role of the teacher is more dominant than the students, seen by control of the teachers in the activities and practice that makes teaching and learning activities more likely as teachercentered learning.

\section{The third teacher}

The teaching and learning activities that implemented by the third teacher signed the grammar explained explicitly or directly from general to specific things. The step by the teacher in teach grammar from the rule then example followed by practice to get direct attention from the students to focus on the form of the rule of grammar is in line with statement by Stern (1992) in Walterowicz (2013, p.117) that stated there are three steps in applying deductive approach, start from the rule then example followed by practice. In addition, the opportunity by the teacher for the students to be active is provided, but the role of the teacher is more dominant than the students, seen by control of the teachers in the activies and practice that makes teaching and learning activities more likely as teacher-centered learning.

\section{The fourth teacher}

The teaching and learning activities that implemented by the fourth teacher signed the grammar explained explicitly or directly from general to specific things. The step by the teacher in teach grammar from the rule then example followed by practice to get direct attention from the students to focus on the form of the rule of grammar is in line with statement by by Stern (1992) in Walterowicz (2013, p.117) that stated there are three steps in applying deductive approach, start from the rule then example followed by practice.

In addition, the opportunity of the teacher for the students to be active is provided, but the role of the teacher is more dominant than the students, seen by control of the teachers in the activities and practice that makes teaching and learning activities more likely as teachercentered learning.

Therefore the result based on the observation of teaching and learning activities in the classroom from four English teachers at SMPN 2 Kota Tangerang, revealed that one teacher 
Globish (An English-Indonesian journal for English, Education and Culture

Vol. 10, No.2, July 2021,

P-ISSN: 2301-9913, E-ISSN: 2597-9132

DOI: http://dx.doi.org/10.31000/globish.v7i2

chooses considered as teacher teaching grammar inductively and three teachers choose considered as teacher teaching grammar deductively in which used by the teachers in the classroom when the researchers did observation that approved by the steps applied by the teachers in teaching and learning activities. Therefore, the researchers get a result of the dominance approach used by the English teachers at SMPN 2 Kota Tangerang is deductive.

\section{CONCLUSION AND SUGGESTION}

The researchers made conclusions from the result of the research as follows : There are two approaches can be used by teachers in teaching grammar termed as deductive and inductive. The approaches have similarities that both deductive and inductive approaches have ease and difficulty or benefit and loss because both deductive and inductive approaches are practical approaches that require the teachers to give the students practice and consider classroom situation, material of grammar that teachers will teach, students' language proficiency, and objectives of the lesson. Meanwhile, deductive and inductive approaches have differences in term of steps, role and domination in the classroom, consideration, advantages, disadvantages, and level of students.

As for the use of an approach, three of four English teachers at SMPN 2 Kota Tangerang use or apply deductive approach in the classroom when the researcher did the observation of teaching and learning process that approved that deductive is the dominance approach that used by English teachers at SMPN 2 Kota Tangerang in teaching grammar.

\section{REFERENCES}

Atta, M.A., Ayaz, M., \& Nawaz, Q. (2015). Comparative Study of Inductive \& Deductive Methods of Teaching Mathematics at Elementary Level . 1 June 2015. Institute of Education and research, Gomal University, Dera Ismail Khan, Pakistan, Institute of Education and research, Uni of Science \& Technology, Bannu, Pakistan. Gomal University Journal of Research [GUJR]. Retrevied from https://ttuir.tdl.org/ttuir/bitstream/handle/2346/12233/31295007622540.pdf;sequenc e=1. (accessed on 10 June 2021).

Berry, R. (2012). English Grammar A Resource Book For Students. New York: Routledge.

Brown, H. D. (2000). Teaching by Principles An Interactive Approach to Language Pedagogy Second Edition. New York : Longman.

DeCapua, A. (2008). Grammar for Teachers: A Guide to American English for Native and NonNative Speakers. New York : Springer.

Harmer, J. (2001). The Practice of Language Teaching Third Edition. Essex : Longman. (2007). The Practice of Language Teaching Third Edition.

Kroeger, P.R. (2005). Analyzing Grammar. New York: Cambridge University Press. 
Globish (An English-Indonesian journal for English, Education and Culture

Vol. 10, No.2, July 2021,

P-ISSN: 2301-9913, E-ISSN: 2597-9132

DOI: http://dx.doi.org/10.31000/globish.v7i2

Nunan, D. (2003). Practical English Language Teaching. New York: The McGraw-Hill Companie

Thornbury, S. (2002). How To Teach Grammar. Harlow: Pearson Education Limited.

Walterowicz, Ł. (2013) A comparative analysis of the effects of teaching writing in a foreign language with the application of the deductive and the inductive approach. University of Lodz. Retreived from http://dspace.uni.lodz.pl:8080/xmlui/bitstream/handle/11089/14957/8- 115 127Walterowicz.pdf?sequence=1\&isAllowed=y. (Accessed on 1 June 2021).

Yürük, N., Şahl'n, T., \& BOZKURT, A.İ. (2000). Comparison of Inductive and Deductive Content Sequence on Students" Chemistry Achievement, Attitudes and Academic Self Concept. Journal of Education 19: 177 - 185. Hacettepe Üniversitesi Eğitim Fakültesi Dergisi 19 : 177-185. Retreived from http://www.efdergi.hacettepe.edu.tr/yonetim/icerik/makaleler/1162published.pdf. (accessed on 20 June 2021). 